University of Nebraska - Lincoln

DigitalCommons@University of Nebraska - Lincoln

Agronomy \& Horticulture - Faculty Publications

Agronomy and Horticulture Department

2-1969

\title{
Absence of Dominance of the Cu Gene in Influencing o- Hydroxycinnamic Acid Content in Melilotus alba
}

Francis A. Haskins

University of Nebraska-Lincoln, fhaskins@neb.rr.com

H. J. Gorz

University of Nebraska-Lincoln

Follow this and additional works at: https://digitalcommons.unl.edu/agronomyfacpub

Part of the Plant Sciences Commons

Haskins, Francis A. and Gorz, H. J., "Absence of Dominance of the Cu Gene in Influencing oHydroxycinnamic Acid Content in Melilotus alba" (1969). Agronomy \& Horticulture -- Faculty Publications. 285.

https://digitalcommons.unl.edu/agronomyfacpub/285

This Article is brought to you for free and open access by the Agronomy and Horticulture Department at DigitalCommons@University of Nebraska - Lincoln. It has been accepted for inclusion in Agronomy \& Horticulture -Faculty Publications by an authorized administrator of DigitalCommons@University of Nebraska - Lincoln. 


\title{
Absence of Dominance of the $\mathrm{C} u$ Gene in Influencing $o$-Hydroxycinnamic Acid Content in Melilotus alba ${ }^{1}$
}

\author{
H. J. Gorz and F. A. Haskins ${ }^{2}$
}

\begin{abstract}
The average content of o-hydroxycinnamic acid in sweetclover plants of the Cucu genotype was $36 \%$ of the level found in $\mathrm{CuCu}$ plants. Thus, the level of $o$-hydroxycinnamic acid in the $F_{1}$ was more like the content of the cucu parent than that of the $\mathrm{CuCu}$ parent, indicating that $c u$ was partially dominant over $C u$. The calculated value for the degree of dominance of $\mathrm{cu}$ over $\mathrm{Cu}$ was +0.299 . The partial dominance of the $c u$ gene provides an explanation for the difficulty experienced in classify. ing plants in segregating populations.
\end{abstract}

Additional index words: Sweetclover, Coumarin.

TN sweetclover (Melilotus alba Desr.), the allelic pair 1 designated $\mathrm{Cu} / \mathrm{cu}$ influences content of $o$-coumaric and coumarinic acid glucosides (the trans and cis isomers of $\beta$-D-glucosyl-o-hydroxycinnamic acid, respectively) apparently by controlling the $o$-hydroxylation of trans-cinnamic acid $(1,8)$. The $c u$ allele was

\footnotetext{
${ }^{1}$ Contribution from the Crops Research Division, Agricultural Research Service, U. S. Department of Agriculture, and the Nebraska Agricultural Experiment Station, Lincoln, Nebr. Supported in part by the National Science Foundation (Grant No. GB-1148). Published with the approval of the Director as Paper no. 2387, Journal Series, Nebraska Agr. Exp. Sta. Received July 24, 1968.

${ }^{2}$ Research Geneticist, Crops Research Division, ARS, USDA, and Bert Rodgers Professor of Agronomy, University of Nebraska, Lincoln 68503, respectively. The assistance of Dr. C. O. Gardner and J. J. Hammond in analyzing the data and the technical assistance of J. F. Hermanussen and A. F. Welty are gratefully acknowledged.
}

derived from $M$. dentata (Waldst. \& Kit.) Pers.; the transfer was effected by interspecific hybridization with $M$. alba, followed by grafting of the albinistic $F_{1}$ hybrids to plants of $M$. officinalis (L.) Lam. (12). Sweetclover plants of the $C u C u$ genotype contain substantial amounts of both o-coumaric acid glucoside and coumarinic acid glucoside (also known as bound coumarin); cucu plants are low in content of both glucosides (6). In tissues that are disrupted, coumarinic acid glucoside is rapidly hydrolyzed by the action of endogenous $\beta$-glucosidase to yield coumarinic acid which lactonizes spontaneously to form coumarin (6). $\beta$-Glucosidase activity is under the control of the $B / b$ alleles $(7,11)$ which are independent of the $\mathrm{Cu} / \mathrm{cu}$ locus. The term "coumarin" has been used extensively in literature pertaining to sweetclover and has a variety of meanings in today's terminology. For example, in some cases the term refers to an unknown portion of the coumarinic acid glucoside or to all of it; but in other cases it designates the sum total of both glucosides. Nevertheless, the term will be retained in some sections below when referring to previous work.

The inheritance of coumarin content in $M$. alba has been studied by several workers but only those investigations dealing with low-coumarin plants derived from the interspecific cross with $M$. dentata will be considered in this review. Smith (13) reported the transfer from $M$. dentata to $M$. alba of two genes influencing coumarin content, one of which displayed 
no dominance. In the light of present-day knowledge, the two allelic pairs referred to by Smith undoubtedly were the $C u / c u$ and $B / b$ genes. Goplen et al. (3) reported that coumarin production in $M$. alba was governed by a single partially dominant gene, for which the symbol $\mathrm{Cu}$ was proposed. They also stated that the average content of $\mathbf{F}_{\mathbf{1}}$ plants was approximately one-half that of the selfs from the high-coumarin parents. Rudorf and Schwarze (10) proposed a two-gene hypothesis in which the homozygous recessive $c u_{1} c u_{1}$ was thought to reduce coumarin content to $1 / 10$ of the normal level, while $\mathrm{Cu}_{2} \mathrm{Cu}_{2}$ reduced the coumarin content from $1 / 10$ to $1 / 100$ of the normal level. Micke (9) obtained $F_{1}$ contents varying from $1 / 10$ to $1 / 2$ of the levels found in parental plants high in coumarinic acid glucoside and observed monofactorial, semidominant segregations in the $F_{2}$ and $F_{3}$ generations.

Although several of the above authors have recognized the intermediate nature of the heterozygote, variability associated with environmental effects and the heterogeneous nature of the plant material used have obscured the precise nature of the dominance inherent in the $C u$ allele. Accordingly, the present experiments were designed to furnish information on the degree of dominance of the $C u$ gene with respect to total content of both coumarinic acid and o-coumaric acid glucosides.

\section{MATERIALS AND METHODS}

Plants of biennial white-blossomed sweetclover (M. alba) of the following two groups of genotypes were used in this study: (1) cucubb, Cucubb, $C u C u b b$, and (2) cucuBB, CucuBB, $C u C u B B$. The four homozygous lines were all derived from an initial $c u c u B B \times C u C u b b$ cross. A single plant, heterozygous for both the $C u / c u$ and $B / b$ alleles, was selfed in each generation from $F_{1}$ to $F_{9}$. Following isolation of the four different homozygous genotypes in $F_{10}$ and $F_{11}, F_{12}$ seed of each genotype was obtained for use in this study. Thus, the four homozygous lines used are closely related and highly inbred.

Seed of the $C u c u b b$ genotype was obtained by crossing $\mathbf{F}_{11}$ plants of the $c u c u b b$ and $C u C u b b$ genotypes, with the $c u c u b b$ plant serving as the female parent. Similarly, the CucuBB genotype was produced by crossing $F_{11}$ plants of the $c u c u B B$ and $C u C U B B$ genotypes, with the $c u c u B B$ plant serving as the female parent. Plants resulting from these crosses were tested qualitatively for coumarinic acid glucoside content. Any plant having a low level was assumed to have resulted from selfing of the cucu parent and was therefore discarded.

Ten plants of each of the six genotypes (listed in groups (1) and (2) above) were established from seed in the greenhouse. During the subsequent months, cuttings were made from each of these 60 plants until a 10-plant clone was available from each. All plants were grown in soil in $10-\mathrm{cm}$ (4-in) clay pots in a greenhouse without supplemental light.

One month before sampling, all plants were cut to a uniform height of approximately $8 \mathrm{~cm}$ so that stage of growth would be as uniform as possible at sampling. At the time of pruning, numbers from 1 to 10 were assigned at random to the plants making up each 10-plant clone. The plants were then arranged on a large greenhouse bench in an incomplete block design with five replications. Each replication was divided into two blocks. Plants from five clones of each genotype were assigned at random to one block; plants from the other five clones were likewise assigned to the other block. The 30 clones once assigned to a block were kept together in each replication. Two plants from each of the $\mathbf{3 0}$ clones assigned to a block, or a total of 60 plants, were randomly arranged within the area assigned to that block on the greenhouse bench. The purpose of the design was to obtain the most precise information possible on genotype means, and at the same time to obtain information on sources of variation involved in the experiment.

Plants were sampled over a period of 5 consecutive days with an entire replicate sampled each day. Each replicate was sam- pled in four groups of 30 plants each. The groups consisted of one plant from each of the five clones of each genotype within a block. Several shoots on each plant were available for sampling. A single shoot was selected on which the youngest fully expanded sample leaf was as nearly comparable as possible in stage of growth, size, color, and location on the plant to the average of the sample leaves obtained from the other plants. The height of the selected shoot was measured in millimeters. A visual score from 1 to 4 was recorded for stage of flowering. Plants with no visible buds were given a score of 1 ; those at a very early, early, or mid-bud stage were given scores of 2,3 , or 4 , respectively. All buds and leaves younger than the leaf to be sampled were removed and the terminal portion of the shoot was cut from the plant and placed in a test tube of water. Each group of 30 shoots was carried to the laboratory, and then placed under fluorescent lights at room temperature for approximately $I$ hour prior to removal of the sample leaves.

Each sample leaf was harvested individually. Immediately after a sample leaf was taken from the shoot, the three leaflets were removed from the petiole. The mid-leaflet, used for the determination of dry-matter percentage, was weighed separately from the two side leaflets, which were extracted and assayed for content of $o$-hydroxycinnamic acid. All weights were made to the nearest $0.1 \mathrm{mg}$ on a direct-reading balance. Extraction was accomplished by dropping the two side leaflets from each plant into $10 \mathrm{ml}$ of boiling water, and autoclaving for $20 \mathrm{~min}$ at approximately 15 psi. Autoclaved extracts were cooled, leaflets were removed and discarded, and the extracts were stored in a freezer for later assay. Previously published procedures $(4,6)$ were followed for assay of the o-hydroxycinnamic acid glucosides.

\section{RESULTS AND DISCUSSION}

Average plant height, flowering stage, and fresh weight of the assay sample for the six genotypes are presented in Table 1. Plants of the cucu genotype were taller and at a more advanced stage of bud formation than $\mathrm{CuCu}$ plants, with the heterozygotes being intermediate in both attributes. Possibly the gene(s) for height and maturity are closely linked to the $C u / c u$ alleles. On the other hand, the glucosides of o-coumaric and coumarinic acids may influence height and flowering stage, resulting in pleiotropic effects of the $\mathrm{Cu} / \mathrm{cu}$ alleles.

Contents of o-hydroxycinnamic acid for each of the 60 clones involved in the study are shown in Table 2. The $B / b$ gene pair appeared to be without effect on $o$-hydroxycinnamic acid content. The average content of $o$-hydroxycinnamic acid in plants of the Cucu genotype was $36 \%$ of the level found in $\mathrm{CuCu}$ plants, whereas cucu plants averaged only $1.25 \%$ of the levels observed in $\mathrm{CuCu}$ plants. The value observed in the present study is within the range of 10 to $50 \%$ reported by Micke (9) for contents of heterozygous $F_{1}$ plants compared with $C u C u$ parents. Highly variable environmental conditions, coupled with the assay procedure used, were probably responsible for the wide range of $F_{1}$ values observed by Micke. His assay method depended upon endogenous enzymatic activity to

Table 1. Average height, flowering stage, and assay sample weight of plants in six genotypes of sweetclover. Each value is the mean of 10 clones with 10 plants per clone.

\begin{tabular}{|c|c|c|c|}
\hline \multirow[b]{2}{*}{ Genotype } & \multicolumn{3}{|c|}{ Mean \pm standard error } \\
\hline & $\begin{array}{c}\text { Plant } \\
\text { height, } \mathrm{mm}\end{array}$ & $\begin{array}{l}\text { Flowering } \\
\text { stage* }\end{array}$ & $\begin{array}{l}\text { Fresh wt., mg, } \\
\text { of assay sample }\end{array}$ \\
\hline $\begin{array}{l}\text { cucubb } \\
\text { cueuBB }\end{array}$ & $\begin{array}{l}356 \pm 7 \\
359 \pm 7\end{array}$ & $\begin{array}{l}1.7 \pm 0.1 \\
1.5 \pm 0.1\end{array}$ & $\begin{array}{l}66.8 \pm 1.4 \\
62.6 \pm 1.4\end{array}$ \\
\hline$\frac{\text { Cucubb }}{\text { CucuBB }}$ & $\begin{array}{l}317 \pm 7 \\
328 \pm 7\end{array}$ & $\begin{array}{l}1.4 \pm 0.1 \\
1.3=0.1\end{array}$ & $\begin{array}{l}62.4 \pm 1,2 \\
63.0 \pm 1,1\end{array}$ \\
\hline$\frac{\mathrm{CuCubb}}{\mathrm{CuCuBB}}$ & $\begin{array}{l}297 \pm 7 \\
296 \pm 6\end{array}$ & $\begin{array}{l}1.2 \neq 0.1 \\
1.1 \pm 0.0 \dagger\end{array}$ & $\begin{array}{l}67.3 \pm 1.2 \\
67.4 \pm 1.3\end{array}$ \\
\hline
\end{tabular}

$3=$ early bud, $4=$ mid-bud, $f$ Actual value was 0.04 . 
Table 2. Average content of o-hydroxycinnamic acid in 10 clones of six genotypes of sweetclover. Ten plants of each clone were sampled.

\begin{tabular}{ccccccc}
\hline $\begin{array}{c}\text { Clone } \\
\text { no. }\end{array}$ & \multicolumn{5}{c}{ Content of o-hydroxycinnamic acid (\% of dry weight) } \\
\cline { 2 - 7 } cucubb & cucuBB & Cucubb & CucuBB & CuCubb & CuCuBB \\
\hline 1 & .047 & .056 & 1.51 & 1.64 & 4.19 & 4.03 \\
2 & .049 & .070 & 1.43 & 1.58 & 4.84 & 5.11 \\
3 & .044 & .054 & 1.78 & 1.73 & 3.98 & 4.18 \\
4 & .053 & .047 & 1.84 & 1.24 & 4.48 & 4.24 \\
5 & .061 & .057 & 1.31 & 1.64 & 5.11 & 4.40 \\
6 & .047 & .042 & 1.30 & 1.63 & 4.36 & 4.71 \\
7 & .059 & .067 & 1.39 & 1.89 & 4.70 & 4.42 \\
8 & .056 & .065 & 1.64 & 1.72 & 4.23 & 4.50 \\
9 & .054 & .064 & 1.63 & 1.81 & 4.57 & 4.52 \\
10 & .051 & .049 & 1.37 & 1.69 & 4.26 & 3.71 \\
Mean & .052 & .057 & 1.52 & 1.66 & 4.47 & 4.38 \\
S.E. & .002 & .002 & 0.04 & $\mathbf{0 . 0 5}$ & $\mathbf{0 . 0 9}$ & 0.09 \\
& cucu mean & .055 & Cucu mean & 1.59 & CuCu mean & 4.43 \\
\hline
\end{tabular}

release o-hydroxycinnamic acid from its combined form, and thus measured only the content of coumarinic acid glucoside. Such methods are influenced greatly by the quality and intensity of light under which the plants are grown, since the content of coumarinic acid glucoside is dependent upon the amount of ultraviolet light received by the leaves (5).

Although Goplen et al. (3) stated that "the average coumarin content of the $F_{1}$ was approximately onehalf that of the selfs of the high-coumarin parent," examination of their data reveals that none of the means of the five $F_{1}$ progenies actually reached $50 \%$ of the average content of the selfed progeny of the high-coumarin parents used in the crosses. Thus mean contents of $F_{1}$ plants derived from crosses of the lowcoumarin parent with the four Arctic parents ranged from $33 \%$ to $49 \%$ of the average content in the selfed progeny from the respective high-coumarin parent, while the value for the $F_{1}$ progeny derived from the cross with Pioneer was only $17 \%$ of the level in Pioneer. For the five $F_{1}$ progenies, the overall mean coumarin content, weighted for the number of plants in each progeny, was $38 \%$ of the weighted mean of the selfed progenies from the high-coumarin parents. This value is only slightly higher than the value of $36 \%$ found in the present study, even though widely different parental plants were used in the two studies.

Numerically, the level of $o$-hydroxycinnamic acid in the $F_{1}$ is clearly more like the content of the cucu parent than that of the $C u C u$ parent, indicating that the $c u$ allele is actually partially dominant over $C u$. This is shown more clearly by calculating the degree of dominance. Using the method of Falconer (2), the degree of dominance of $c u$ over $C u$ was found to be +0.299 , verifying the complete absence of dominance of the $C u$ allele and the partial dominance of $c u$.

The partial dominance of $c u$ is in apparent disagreement with the results of other studies in which $\mathrm{F}_{2}$ ratios of three high-coumarin to one low-coumarin have been reported $(3,9)$. This disagreement is readily understood when one considers that the fluorometric procedure for the detection of $o$-hydroxycinnamic acid is so sensitive that, in a qualitative test, the levels of o-hydroxycinnamic acid occurring in Cucu plants may be classified as high. Even with a quantitative assay, the unequivocal classification of Cucu and CuCu plants is difficult because of the variation encountered in assaying plants within a genotype.

From the present study, it is evident that there also is the danger of misclassifying cucu and Cucu plants, a situation previously observed in genetic studies con- ducted by Micke (9). At the Nebraska Experiment Station, this problem has been particularly troublesome in screening large populations of segregating lines in the field in the development of low-o-hydroxycinnamic acid varieties of sweetclover. Any condition that tends to reduce plant vigor, such as insect or disease damage, inadequate nodulation, drouth, shading, or a lack of suitable nutrients, tends to decrease the content of $o$-hydroxycinnamic acid. Thus the difficulty of separating heterozygotes from cucu plants is increased, resulting in the inclusion of some heterozygous plants in a supposedly uniform group of cucu plants.

The dominance relationships observed in this study suggest that the $C u$ symbol should be used to denote a plant low in o-hydroxycinnamic acid, while $c u$ should refer to a plant high in $o$-hydroxycinnamic acid. This usage would also be consistent with quantitative genetics notation where the capital letter is used to designate the more favorable allele. Low o-hydroxycinnamic acid level is desirable in sweetclover from the standpoint of the use of this plant for forage. However, retention of the use originally ascribed to these symbols by Goplen et al. (3) seems wise, because separation of heterozygotes, from homozygous plants high in content of o-hydroxycinnamic acid, is virtually impossible when qualitative fluorometric procedures are used. In addition, retaining present usage would help to prevent the confusion of terms in the literature.

\section{LITERATURE CITED}

1. Brown, S. A. 1963. Recent studies on the formation of natural coumarins. Lloydia 26:211-222.

2. Falconer, D. S. 1960. Introduction to quantitative genetics. The Ronald Press Co., New York.

3. Goplen, B. P., J. E. R. Greenshields, and H. Baenziger. 1957. The inheritance of coumarin in sweet clover. Can. J. Bot. 35:583-593.

4. Gorz, H. J., and F. A. Haskins. 1964. Occurrence of $o$-hydroxycinnamic acid in species of Melilotus and Trigonella. Crop Sci. 4:193-196.

5. Gorz, H. J., F. A. Haskins, and A. Kleinhofs. 1966. Genetic and biochemical aspects of $o$-hydroxycinnamic acid synthesis in Melilotus alba. Int. Grassland Congr., Proc. 10th. p. 704-708.

6. Haskins, F. A., and H. J. Gorz. 1961. A reappraisal of the relationship between free and bound coumarin in Melilotus. Crop Sci. 1:320-323.

7. Haskins, F. A., and H. J. Gorz. 1965. Absence of dominance of the $B$ gene in influencing $\beta$-glucosidase activity in Melilotus alba. Genetics 51:733-738.

8. Haskins, F. A., and T. Kosuge. 1965. Genetic control of the metabolism of o-hydroxycinnamic acid precursors in Melilotus alba. Genetics 52:1059-1068.

9. Micke, A. 1962. Genetisch Untersuchungen beim weissen Steinklee (Melilotus albus). I. Úber die Vererbung der Fähigkeit zur Bildung von Cumarinsäureglykosid. Z. Pflanzenzücht. 48:1-13.

10. Rudorf, W., and P. Schwarze. 1958. Beiträge zur Züchtung eines cumarinfreien Steinklees und Untersuchungen über Cumarin und verwandte Verbindungen. Z. Pflanzenzucht. 39:245-274.

11. Schaeffer, G. W., F. A. Haskins, and H. J. Gorz. 1960. Genetic control of coumarin biosynthesis and $\beta$-glucosidase activity in Melilotus alba. Biochem. Biophys. Res. Comm. 3:268-271.

12. Smith, W. K. 1943. Propagation of chlorophyll-deficient sweetclover hybrids as grafts. J. Hered. 34:135-140.

13. Smith, W. K. 1948. Transfer from Melilotus dentata to $M$. alba of the genes for reduction in coumarin content. Genetics 33:124-125. 